\title{
Effects of Long-Term Livestock Grazing on Fuel Characteristics in Rangelands: An Example From the Sagebrush Steppe
}

\author{
Kirk W. Davies, ${ }^{1}$ Jonathan D. Bates, ${ }^{1}$ Tony J. Svejcar, ${ }^{2}$ and Chad S. Boyd ${ }^{1}$ \\ Authors are ${ }^{1}$ Rangeland Scientists and ${ }^{2}$ Research Leader, United States Department of Agriculture-Agricultural Research Service, Eastern Oregon \\ Agricultural Research Center, 67826-A Hwy 205, Burns, OR 97720, USA.
}

\begin{abstract}
Livestock grazing potentially has substantial influence on fuel characteristics in rangelands around the globe. However, information quantifying the impacts of grazing on rangeland fuel characteristics is limited, and the effects of grazing on fuels are important because fuel characteristics are one of the primary factors determining risk, severity, continuity, and size of wildfires. We investigated the effects of long-term $(70+\mathrm{yr})$ livestock grazing exclusion (nongrazed) and moderate levels of livestock grazing (grazed) on fuel accumulations, continuity, gaps, and heights in shrub-grassland rangelands. Livestock used the grazed treatment through 2008 and sampling occurred in mid- to late summer in 2009. Nongrazed rangelands had over twofold more herbaceous standing crop than grazed rangelands $(P<0.01)$. Fuel accumulations on perennial bunchgrasses were approximately threefold greater in nongrazed than grazed treatments. Continuity of fuels in nongrazed compared to grazed treatments was also greater $(P<0.05)$. The heights of perennial grass current year's and previous years' growth were 1.3 -fold and 2.2 -fold taller in nongrazed compared to grazed treatments $(P<0.01)$. The results of this study suggest that moderate livestock grazing decreases the risk of wildfires in sagebrush steppe plant communities and potentially other semi-arid and arid rangelands. These results also suggest wildfires in moderately grazed sagebrush rangelands have decreased severity, continuity, and size of the burn compared to longterm nongrazed sagebrush rangelands. Because of the impacts fuels have on fire characteristics, moderate levels of grazing probably increase the efficiency of fire suppression activities. Because of the large difference between fuel characteristics in grazed and nongrazed sagebrush rangelands, we suggest that additional management impacts on fuels and subsequently fires need to be investigated in nonforested rangelands to protect native plant communities and prioritize management needs.
\end{abstract}

\section{Resumen}

El pastoreo del ganado tiene una influencia fundamental sobre las características de los combustibles en los pastizales alrededor del mundo. Sin embargo, información que mida los impactos del pastoreo en las características de los combustibles de los pastizales es limitada. Los efectos que tiene el pastoreo en los combustibles son importantes ya que las características de los combustibles son uno de los factores más importantes para determinar el riesgo, severidad, continuidad, y tamaño de los incendios de pastizales. Investigamos los efectos del la exclusión del pastoreo (no pastoreo) a largo plazo ( +70 años) y niveles moderados de pastoreo por el ganado en la acumulación de combustibles, continuidad, espacios y alturas en pastizales compuestos de arbusto-pastos. El ganado fue utilizado en los tratamientos de pastoreo durante el 2008 y las muestras se tomaron desde mediados y hasta finales del verano del 2009. Pastizales sin pastoreo tuvieron $>2$ veces más producción herbácea que las áreas pastoreadas $(P<0.01)$. La acumulación de combustibles en zacates amacollados fue aproximadamente 3 veces mayor en los tratamientos sin pastoreo que en los tratamientos pastoreados. La continuidad del combustible en tratamientos sin pastoreo en comparación con los tratamientos de pastoreo fue también mayor $(P<0.05)$. La altura de los pastos perennes en el año en curso y el año posterior fueron 1.3 y 2.2 veces más altas en tratamientos sin pastoreo comparado con los tratamientos pastoreados $(P<0.01)$. Los resultados de este estudio sugieren que el pastoreo moderado por el ganado disminuye el riesgo de un incendio en las comunidades de plantas en los pastizales de "sagebrush" y potencialmente en otros pastizales semiáridos y áridos. Estos resultados también sugieren que los incendios naturales en pastizales de "sagebrush" pastoreados moderadamente han disminuido en severidad, continuidad y tamaño de los incendios comparados con los pastizales de "sagebrush" con largos periodos sin pastoreo. Debido al impacto que los combustibles tienen sobre las características del fuego, niveles moderados de pastoreo probablemente incrementan la eficacia en el control de incendios. Debido a la gran diferencia entre las características de los combustibles en pastizales de "sagebrush" pastoreados y no pastoreados, sugerimos un manejo adicional de los impactos sobre los combustibles y subsecuentemente los incendios necesitan ser investigados en pastizales no-boscosos para proteger comunidad de plantas nativas y priorizar las necesidades de manejo.

Key Words: Artemisia arbuscula, Artemisia tridentata, bunchgrass, cattle, fire, fuel management, wildfire, wildfire risk

The Eastern Oregon Agricultural Research Center is jointly funded by the United States Department of Agriculture-Agricultural Research Service and Oregon State University.

Mention of a proprietary product does not constitute a guarantee or warranty of the product by USDA or the authors and does not imply its approval to the exclusion of other products.

Correspondence: Kirk W. Davies, United States Department of Agriculture-Agricultural Research Service, Eastern Oregon Agricultural Research Center, 67826-A Hwy 205, Burns, OR 97720, USA.Email: kirk.davies@oregonstate.edu

Manuscript received 4 January 2010; manuscript accepted 7 September 2010.

\section{INTRODUCTION}

Because livestock grazing and fire occur across most rangelands around the world, grazing-induced modifications to fuel characteristics are probably having a substantial impact on many plant communities (Davies et al. 2009). Domestic cattle graze large expanses of shrub and grasslands in the arid and 
semi-arid regions of Africa, Americas, Australia, and Asia. Many of these areas are also prone to wildfire and/or are occasionally prescribed burned. Grazing has the potential to significantly affect fire characteristics (Blackmore and Vitousek 2000; Kerby et al. 2007; Waldram et al. 2008). For example, historical heavy livestock grazing in forests altered fuel characteristics, decreasing the likelihood of low severity wildfires and increasing the probability of high severity wildfires in forest systems by increasing small tree densities (Zimmerman and Neuenschwander 1984; Belsky and Blumenthal 1997). Heavy grazing reduced competition experienced by seedling trees by reducing the herbaceous understory, and the reduction in the herbaceous understory also reduced the frequency of light severity fires that would have removed small trees (Zimmerman and Neuenschwander 1984; Belsky and Blumenthal 1997). Historical heavy grazing by livestock that caused these changes in forest stand dynamics is not the same as current managed livestock grazing (Borman 2005). Thus, little is known regarding the impact of moderate levels of livestock grazing (35-50\% of available forage with alternating timing of use) on fuel characteristics, especially in rangelands.

Understanding the impact of grazing on fuels in rangelands is important because fuel characteristics influence wildfire risk, severity, continuity, and size, and the effectiveness of fire suppression efforts. Waldram et al. (2008) demonstrated that white rhino grazing decreased fuel loads and continuity in South Africa. Subsequently, white rhino removals resulted in larger, less patchy fires (Waldram et al. 2008). In forested systems, fuel characteristics have been demonstrated to influence fire size, severity, and suppression effectiveness (Moghaddas and Craggs 2007; Ritchie et al. 2007). The need to understand the impacts of management on fuels is widely recognized in forested systems (Wimberly et al. 2009). However, the impact of moderate levels of grazing on fuel heights, amounts, spatial arrangement, and continuity remains largely unexplored in rangelands. Davies et al. (2009) reported that there appeared to be greater fine fuel accumulations on perennial bunchgrass in nongrazed compared to grazed rangelands, suggesting that grazing influenced the total and spatial accumulations of fuels. However, Davies et al. (2009) did not empirically test grazing effects on fuels. Blackmore and Vitousek (2000) measured a decrease in total fine fuel accumulations and grass canopy heights with grazing in dry forests of Hawaii. Similarly, Briggs et al. (2002) reported that grazing in the tallgrass prairie reduced fine fuel loads by more than $30 \%$. Archibald et al. (2009) reported that higher grazing density was an important factor limiting the area burnt in southern Africa. The previous studies evaluated the immediate effects of grazing, but a more complete understanding of grazing effects on fuel characteristics will require long-term research to allow cumulative effects to be expressed. Furthermore, studies need to measure fuel characteristics after the main growing season, during the wildfire season, and before livestock grazing to determine if effects are more than just immediate impacts of grazing on current year's plant production. Measuring fuel characteristics before annual livestock grazing also provides important information for two common scenarios. First, the season of livestock grazing use is sometimes rotated among pastures (Holechek et al. 1998), thus wildfires frequently burn plant communities that were not grazed immediately before the fire, but are experiencing the influence of long-term grazing. Second, prescribed burns in arid and semi-arid systems often require that grazing be curtailed for $1 \mathrm{yr}$ to build up enough fuels for a successful burn under climatic conditions that allow for effective control (Bunting et al. 1987).

Long-term exclusion of livestock grazing would allow multiple years of plant growth to accumulate. In dry systems, where decomposition is relatively slow (Coûteaux et al. 1995), accumulations may significantly increase the fine fuel loads. Long-term grazing may also cause plant community compositional changes that influence fuel characteristics that would not be evident in short-term studies. In some forested systems, long-term heavy grazing has caused a shift from herbaceous species to more small trees (Zimmerman and Neuenschwander 1984) and in South African savanna, long-term heaving grazing results in the spread of nonflammable stoloniferous species (Waldram et al. 2008). Derner and Whitman (2009) reported a shift in perennial grass dominance with long-term heavy grazing in the northern mixedgrass prairie that influenced fuel continuity. Thus, to determine the impact of moderate levels of grazing on fuels in rangelands, longterm grazing and nongrazing treatments are needed.

The need to understand the effects of grazing on fuels in rangelands is also critical because of the threat of invasive plants. Fuel accumulations have the potential to increase the severity of the fire, which can open native plant communities to exotic plant invasion. Davies et al. (2009) suggested that fuel accumulations, by increasing fire severity, were probably the cause of a postfire invasion of exotic annual grass in pristine shrub-grassland communities. Fuel characteristics can also influence the probability of wildfire risk. Because exotic plant invasions are often facilitated by fire in native plant communities (Stohlgren et al. 1999; Chambers et al. 2007), the influence of fuel on wildfire risk also affects the threat of exotic plant invasions. Therefore, it is critical to determine the impact of grazing on fuels in rangelands to sustain native rangeland plant communities and the fauna dependent upon them.

To determine the impact of grazing on fuel characteristics in rangelands, we investigated the effects of long-term $(70+\mathrm{yr})$ livestock exclusion compared to long-term moderate livestock grazing in semi-arid, sagebrush (Artemisia L.) steppe plant communities in the northern Great Basin. We hypothesized that livestock grazing would 1) reduce fine fuel accumulations, 2) alter the spatial arrangement of fuels, and 3) decrease fuel continuity (consistency of fuels across space).

\section{METHODS}

\section{Study Area}

The study was conducted at the 6475-ha Northern Great Basin Experimental Range (NGBER) in southeastern Oregon (lat $43^{\circ} 29^{\prime} \mathrm{N}$, long $\left.119^{\circ} 43^{\prime} \mathrm{W}\right)$, about $56 \mathrm{~km}$ west of Burns, Oregon. Climate at the NGBER is representative of the northern Great Basin with cool, wet winters and hot, dry summers. The NGBER headquarters received on average $300 \mathrm{~mm}$ of precipitation annually during the past $50 \mathrm{yr}$ (1956-2005). Annual precipitation for plant growth (1 October-30 September) in 2004, 2005, 2006, 2007, 2008, and 2009 was $120 \%, 118 \%, 71 \%, 80 \%, 66 \%$, and $88 \%$ of the long-term average, respectively. Elevation at the study sites 
ranges from $1360 \mathrm{~m}$ to $1520 \mathrm{~m}$ above sea level. Topography at the study sites is variable with slopes ranging from $0^{\circ}$ to $15^{\circ}$ and aspects from north to south. Soils at the study sites are Aridisols, Mollisols, and Andisols with shallow to moderately deep soil profiles before reaching a restrictive layer. Dominant vegetation varied by study site. Mountain big sagebrush (Artemisia tridentata subsp. vaseyana [Rydb.] Beetle), Wyoming big sagebrush (A. tridentata subsp. wyomingensis [Beetle and A. Young] S. L. Welsh), or low sagebrush (A. arbuscula Nutt.) was the dominant shrub depending on study site. Dominant perennial bunchgrass was Thurber's needlegrass (Achnatherum thurberianum [Piper] Barkworth), Idaho fescue (Festuca idahoensis Elmer), or bluebunch wheatgrass (Pseudoroegneria spicata [Pursh] A. Löve). Other common perennial bunchgrass species in the study area included prairie junegrass (Koeleria macrantha [Ledeb.] J. A. Schultes), squirreltail (Elymus elymoides [Raf.] Swezey), needle and thread (Hesperostipa comata [Trin. and Rupr.] Barkworth), Sandberg bluegrass (Poa secunda J. Presl), and Indian ricegrass (Achnatherum hymenoides [Roem. and Schult.] Barkworth). The plant communities used in this study are common across the Intermountain West (Daubenmire 1970; Davies et al. 2006; Davies and Bates 2010) and are not believed to have recently evolved with high numbers of large herbivores (Mack and Thompson 1982). Historical fire return intervals are estimated to be $50-100+$ yr for the less productive sagebrush plant communities (Wright and Bailey 1982; Mensing et al. 2006) and $<25 \mathrm{yr}$ for more productive sagebrush plant communities (Miller and Rose 1999; Miller and Heyerdahl 2008).

\section{Experimental Design}

To determine the effect of grazing on fuel characteristics, we used a randomized block design with two treatments (grazed and nongrazed). Treatments were applied at eight different sites with differing vegetation, soils, and topography. Nongrazed treatments were 2-ha livestock grazing exclosures established in 1936. Native herbivores, including but not limited to mule deer, pronghorn, elk, and rodents, had access to vegetation inside the exclosures. The grazed treatment plots were located adjacent to the exclosures and within the same soil, topography, and vegetation association as the exclosures. Density data collected in 1937 revealed no differences in Sandberg bluegrass, large perennial bunchgrass grasses, annual grasses, perennial forbs, and annual forbs between inside and outside the exclosures $(P>0.05)$. The grazed treatments adjacent to the exclosures were grazed by cattle through 2008. Grazed treatments were moderate, $30-50 \%$ use of the available forage. From 1938 to 1949 livestock use was rotation grazing with stocking rates determined from range surveys conducted in 1938 and 1944. From 1949 to 2008, the grazing program was a deferred-rotational system with an occasional year of complete rest. Grazing pressure ranged between 0.15 and 0.36 animal unit months (AUMs) per hectare with the average pressure of 0.22 AUMs per hectare. No grazing occurred prior to sampling in 2009. Grazing sites were in eight different pastures ranging in size from 65 ha to 810 ha.

\section{Measurements}

Fuel characteristics were sampled in late July and early August of 2009. This time period coincides with the wildfire season and the peak of the dry and hot period in this region. Each site was sampled using a $30 \times 60 \mathrm{~m}$ plot centered in the treatment plot to limit edge effects. Four 20-m transects, spaced at $15-\mathrm{m}$ intervals, were established in each $30 \times 60 \mathrm{~m}$ plot. Fuel cover, by cover type, was measured along each 20 -m transect using the line-intercept method (Canfield 1941). Cover types included perennial bunchgrass, total herbaceous vegetation, ground litter, fuel gaps (areas lacking fuels), and shrubs. Herbaceous vegetation cover measurements included current and previous years' standing growth. Shrub cover included live and dead standing cover. Fuel biomass was measured by clipping herbaceous standing crop (current and previous years' erect vegetation) and gathering ground litter (litter between herbaceous plants) inside $151-\mathrm{m}^{2}$ frames randomly located in each $30 \times 60 \mathrm{~m}$ plot. Herbaceous biomass was oven dried, separated into current and previous years' growth, and then weighed. The current year's growth was used to determine herbaceous annual biomass production. Ground litter was oven dried and then weighed. Fuel biomass accumulations on individual perennial bunchgrasses were determined by clipping 20 randomly selected perennial bunchgrasses in each $30 \times 60 \mathrm{~m}$ plot. Perennial bunchgrass fuel accumulations were oven dried, separated into current and previous years' growth, and then weighted. Perennial bunchgrass heights were measured by randomly selecting 50 individuals and measuring the tallest current and previous years' growth.

\section{Statistical Analysis}

Analysis of variance was used to determine the influence of grazing on fuel characteristics by comparing the moderately grazed treatment to the long-term nongrazed treatment (S-Plus v.8; Insightful Corp, Seattle, WA). The eight sites were treated as blocks in the analyses. Differences between means were considered significant if $P$-values were equal to or less than $0.05(\alpha=0.05)$. Means are reported with standard errors $($ mean $+\mathrm{SE})$. For analyses, fuel cover was separated into the following cover types: perennial bunchgrass, total herbaceous vegetation, ground litter, fuel gaps, and shrubs. Total herbaceous cover was the sum of perennial bunchgrass and other herbaceous vegetation cover. Fuel loads were analyzed as total herbaceous vegetation standing crop, current year's herbaceous vegetation biomass, ground litter, and total fine fuels (standing crop plus ground litter). Perennial bunchgrass fuel accumulations were analyzed as total accumulations, current year's biomass, and previous years' biomass. Perennial bunchgrass heights were analyzed as current and previous years' growth.

\section{RESULTS}

\section{Fuel Cover and Gaps}

Long-term moderate levels of livestock grazing generally decreased the amount (Fig. 1) and continuity (Fig. 2) of fuel cover in rangelands. Perennial grass and total herbaceous cover were less in grazed than nongrazed treatments $(P=0.01$ and $<0.01)$. The perennial bunchgrass cover was approximately twofold more in the ungrazed compared to the grazed treatments. Total herbaceous cover was about 1.5 -fold more in the exclosures than the grazed treatments $(P<0.01)$. Gaps in 


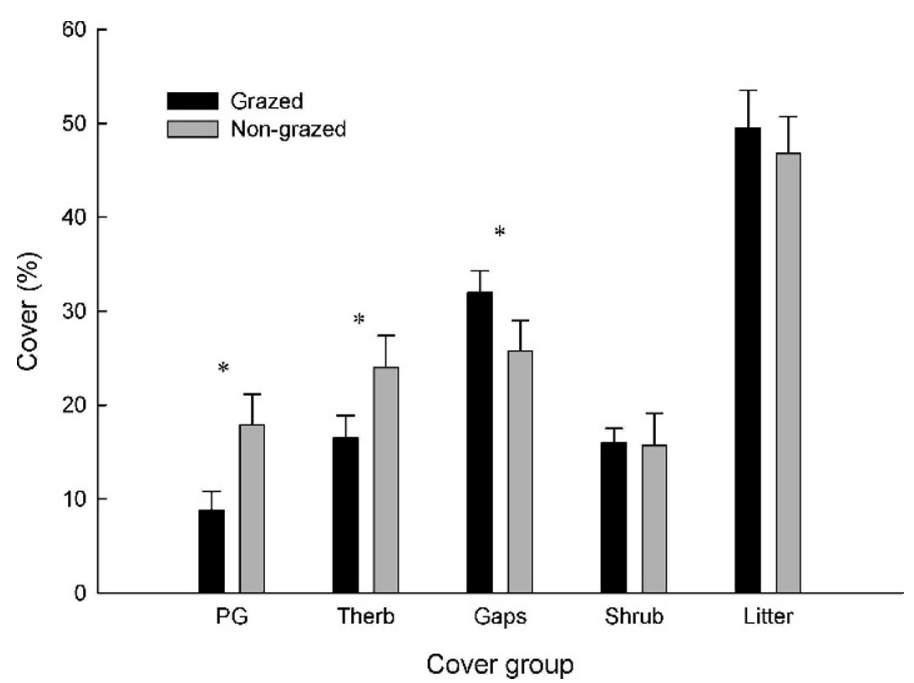

Figure 1. Percent cover (mean $+\mathrm{SE}$ ) by group in moderately grazed and nongrazed sagebrush rangelands. Vegetation cover measurements included live and dead standing cover. PG indicates perennial bunchgrass; Therb, total herbaceous vegetation; Gaps, fuel gaps; Shrub, sagebrush and other shrubs; and Litter, ground litter. Asterisks ( $\left.{ }^{*}\right)$ indicate significant difference between treatments $(P<0.05)$.

the fuel covered more soil surface in grazed than nongrazed treatments $(P=0.04)$. Fuel gap cover was 1.2 -fold greater in the grazed compared to nongrazed treatments. In contrast to the other cover values, shrub and ground litter cover values were not different between treatments $(P=0.91$ and 0.25 , respectively).

Livestock influence on fuel continuity varied by cover type (Fig. 2). The nongrazed treatment had larger continuous (without a gap in it) perennial bunchgrass cover and smaller

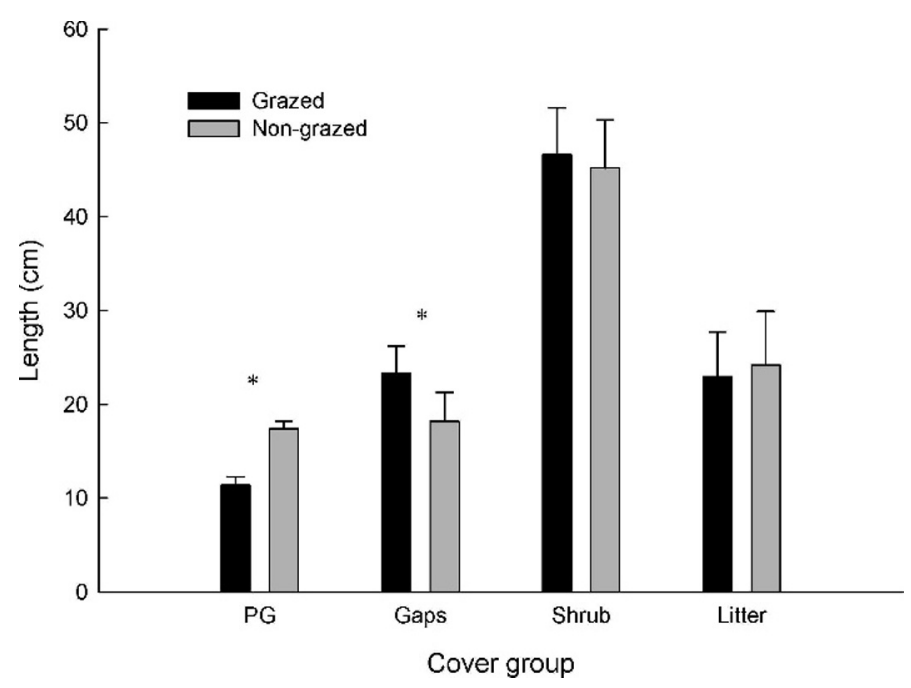

Figure 2. Continuous cover length (mean $+\mathrm{SE}$ ) by group in moderately grazed and nongrazed sagebrush rangelands. Continuous vegetation cover is cover without a gap in it and continuous gap cover is a gap in cover without any vegetation cover in it. Vegetation cover measurements included live and dead standing cover. PG indicates perennial bunchgrass; Gaps, fuel gaps; Shrub, sagebrush and other shrubs; and Litter, ground litter. Asterisks $\left({ }^{*}\right)$ indicate significant difference between treatments $(P<0.05)$.

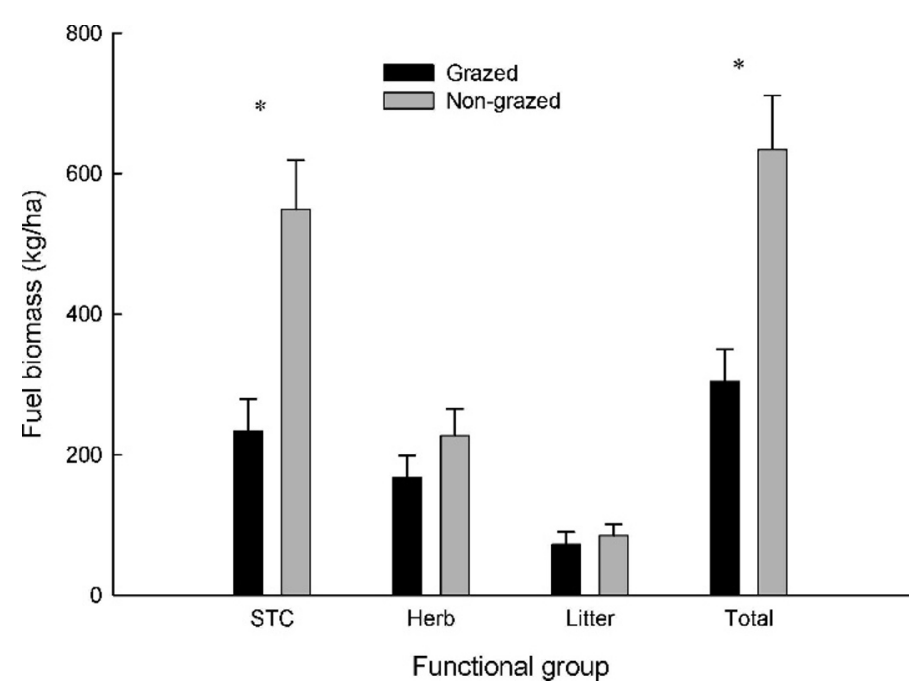

Figure 3. Fuel accumulations (mean $+\mathrm{SE}$ ) by functional group in moderately grazed and nongrazed sagebrush rangelands. STC indicates herbaceous vegetation standing crop (current and past years' growth still erect); Herb, current year's herbaceous vegetation growth; Litter, ground litter; and Total, herbaceous vegetation standing crop and litter. Asterisks $\left({ }^{*}\right)$ indicate significant difference between treatments $(P<0.05)$.

fuel gaps $(P<0.01$ and $=0.03$, respectively). The length of continuous perennial grass cover was 1.5 -fold longer in the nongrazed compared to the grazed treatments. The length of fuel gaps were about 1.3-fold longer in the grazed than nongrazed treatments. Shrub and ground litter cover continuity did not differ by treatment $(P=0.73$ and 0.55 , respectively).

\section{Fuel Loads}

Livestock grazing influenced some of the fuel load characteristics in rangeland plant communities (Fig. 3). The nongrazed treatment had greater herbaceous standing crop biomass than the grazed treatment $(P<0.01)$. Herbaceous vegetation standing crop biomass was more than twofold greater in nongrazed than grazed treatments. Total fine fuel accumulations varied by treatment $(P<0.01)$. Total fine fuel accumulations were twofold higher in nongrazed compared to grazed treatments. However, ground litter did not differ between treatments $(P=0.48)$. A difference in herbaceous vegetation annual biomass production between treatments was not detected $(P=0.21)$.

\section{Perennial Grass Fuel Characteristic}

Livestock grazing also influenced the fuel characteristics of perennial bunchgrasses. Fuel accumulations on top of perennial bunchgrass crowns were more than 2.8-fold greater in the nongrazed compared to grazed treatments ( $P<0.01$; Fig. 4A). However, a difference in perennial bunchgrass current year's biomass production between the treatments was not detected $(P=0.11)$. Average heights of perennial bunchgrasses were greater in the nongrazed than grazed treatments $(P<0.01$; Fig. 4B). Perennial bunchgrasses were 1.3-fold taller in the nongrazed compared to grazed treatment. Similarly, previous years' growth was also taller in the nongrazed compared to grazed treatments $(P<0.01)$. Previous years' growth of 


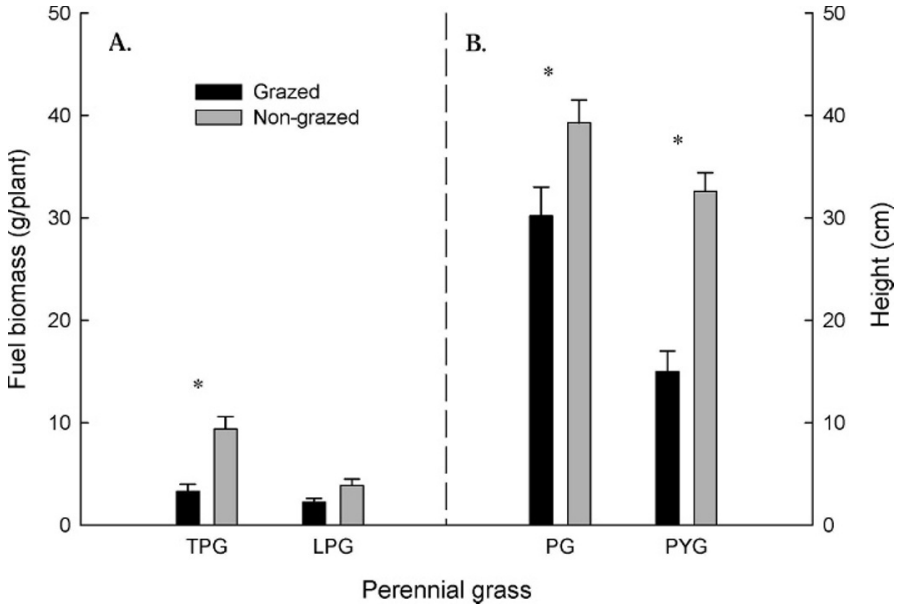

Figure 4. Fuel accumulations (A) and heights (B; mean $+\mathrm{SE})$ of perennial bunchgrass in moderately grazed and nongrazed sagebrush rangelands. TPG indicates current and previous years' biomass; LPG, current year's biomass; PG, current year's growth; and PYG, previous years' growth. Asterisks $\left(^{*}\right)$ indicate significant difference between treatments $(P<0.05)$.

perennial bunchgrasses was 2.2-fold taller in the nongrazed than grazed treatments.

\section{DISCUSSION}

Moderate livestock grazing on sagebrush rangelands influences fuel accumulations, continuity, and height, which in turn influences burn characteristics and wildfire risk. Our data demonstrate that moderate levels of livestock grazing decrease fine fuel loading and continuity. These alterations have the potential to decrease the probability, continuity, size, and severity of wildfires in sagebrush rangelands. Livestock grazing impacts several fuel characteristics simultaneously. This greatly increases its potential influence on wildfires. The influence of grazing on fuels, by affecting fire severity, may also affect postfire plant community response and assembly in sagebrush plant communities and potentially other semi-arid and arid rangelands.

Contrary to the impacts reported from heavy grazing in forested systems (Zimmerman and Neuenschwander 1984; Belsky and Blumenthal 1997), moderate long-term grazing in sagebrush rangelands appears to decrease the probability of severe, catastrophic wildfires. Our results support speculation by others (Conrad and Poulton 1966; Davies et al. 2009) that moderate grazing can reduce fuel accumulation and may subsequently reduce fire severity. The lower accumulation of fuel, especially on the perennial bunchgrass crowns, would decrease the likelihood of a severe wildfire. Heavy grazing in forested systems can increase small woody vegetation (Zimmerman and Neuenschwander 1984), whereas moderate levels of grazing on sagebrush rangeland did not appear to influence woody vegetation (Figs. 1 and 2). Thus, differences in fuel accumulations were a result of herbaceous vegetation. The differences in fuel accumulations between moderately grazed and nongrazed rangelands in this study would have been even more pronounced if grazing would have occurred in the sampling year prior to sampling. However, by not allowing grazing of the current years' plant growth, we were able to establish that the influence of grazing on fuels in sagebrush rangelands is not limited to just the predicable immediate effect of grazing removing current years' plant growth. Considering our results in context with studies evaluating the immediate effects of grazing on fuel loads (Blackmore and Vitousek 2000; Briggs et al. 2002), moderate levels of livestock grazing are probably reducing the severity of wildfires on rangelands globally.

The probability of burning and burn continuity may be decreased in moderately grazed sagebrush rangelands because of a reduction in fine fuels, larger gaps between fuels, less continuous fuels, and shorter fine fuel heights. The height and amount of fine fuels are correlated positively with the ability of fire to spread, especially across fuel gaps (Bradstock and Gill 1993; Blackmore and Vitousek 2000). Similarly, Miller and Heyerdahl (2008) reported that variation in fire frequency in rangelands was driven by fine fuel abundance and continuity, and Miller and Urban (2000) demonstrated that fine fuels from grass were critical for fire spread and were correlated positively with increasing fire frequency in drier plant communities. Waldram et al. (2008) also reported that the removal of a large herbivore in Africa increased the fuel loads and continuity and this caused larger fires with less unburned patches. Larger fuel gaps in moderately grazed sagebrush rangelands would require longer flame heights to be crossed; however, the effects of grazing on other fuel characteristics would decrease flame lengths. Less fine fuel and shorter fuel height produces shorter flame lengths (Bradstock and Gill 1993). Thus, moderate grazing affects several fuel characteristics to cumulatively decrease the flammability of sagebrush rangelands. The probability of burning and the continuity of the burn would be influenced by the rate of spread, which would be slower in the moderately grazed compared to nongrazed treatments. Blackmore and Vitousek (2000) reported that a reduction in fine fuel amounts and heights greatly suppressed the rate of fire spread. Shorter flame lengths and a reduced rate of spread in moderately grazed sagebrush rangelands would probably also increase the effectiveness of suppression efforts.

Moderate livestock grazing is probably directly and indirectly lengthening fire return intervals in native sagebrush rangelands. Directly, livestock are reducing fuels that would promote ignition and spread and indirectly, livestock are increasing the effectiveness of fire suppression. Similarly, livestock grazing in combination with fire suppression has probably lengthened fire intervals in forested systems (Schoennagel et al. 2004). However, extreme climatic conditions during a fire may reduce the effects of livestock grazing on fires. Fire spread is correlated to fuels and climatic conditions, with wind having a strong effect (Cheney et al. 1993). Gedalof et al. (2005) reported that fuel treatments in forested systems may not be effective at reducing the area burned under extreme climatic conditions. Fuels appear to be more important than climate in determining fire spread and severity in drier ecosystems (Schoennagel et al. 2004). Regardless, under similar climatic conditions, long-term nongrazed compared to moderately grazed sagebrush rangelands would be more likely to burn, burn with less patches of unburned within the burn perimeter, and produce fires that would be more difficult to suppress. 
Moderate levels of cattle grazing in sagebrush plant communities also affect the spatial arrangement of fuels. Moderate grazing reduced the accumulation of fuels on perennial bunchgrass crowns, but did not alter the accumulation of fine fuels between plants. Thus, moderate grazing reduces the heterogeneity of fuels between perennial grass crowns and interspaces. This alteration of spatial heterogeneity of fuel accumulations would impact the variability of fire severity within the plant community. By reducing the fuel accumulations on perennial bunchgrasses, grazing decreases the potential for fire-induced mortality of perennial grasses. Fuel accumulations on perennial grasses would increase their probability of suffering fire-induced mortality (Odion and Davis 2000; Davies et al. 2009). Micro-site fuel accumulations increase soil heating and this elevates the vulnerability of perennial grasses to fire (Odion and Davis 2000).

The effect of moderate grazing on fuel accumulation on perennial bunchgrasses has significant implications to postfire plant community recovery and assembly. Perennial bunchgrasses, as the dominant herbaceous functional group, are the most critical vegetation to preventing exotic plant invasions in sagebrush rangelands (Davies 2008; James et al. 2008). A decrease in perennial bunchgrass densities from fire-induced mortality allowed Wyoming big sagebrush plant communities to be invaded by an exotic annual grass (Davies et al. 2009). Complete exclusion of livestock grazing compared to moderate livestock grazing would increase the probability of postfire exotic plant invasion by increasing the risk of fire-induced mortality of perennial bunchgrasses.

The results of this study also suggest that fuel management needs to be a larger concern on rangelands. Management of fuels in forested systems has long been recognized as needed to decrease fire severity and facilitate desirable postfire plant community responses (Dodge 1972; Allen et al. 2002; Mitchell et al. 2009). Recently, the public has started to recognize the need for fuel treatments in forests. Large stand-replacing wildfires have increased public concern and recognition of the need for fuel treatments to reduce fire hazards in forests (Schwilk et al. 2009). Despite the recent increase in awareness of fuel management needs in forests, native rangelands are rarely the focus of fuel management or research. However, rangeland plant communities with much lower fuel loads than traditionally targeted for fuel management may need fuelreducing management to prevent undesirable postfire plant community responses (Davies et al. 2009). Our research demonstrates that management actions (moderate grazing or not grazing) in rangeland systems can have significant impacts on fuel characteristics. Understanding the interactions between fire and grazing is critical to proper rangeland management (Archibald et al. 2005). Thus, the effect of fuel management on rangeland plant communities will need to be addressed, especially with the threat of invasive plants and continued climate change.

Moderate levels of cattle grazing, by reducing the risk of catastrophic wildfires and postfire exotic plant invasions, may protect sagebrush rangeland plant communities and the fauna dependent upon them. Beck et al. (2009) and Rhodes et al. (2010) measured a decrease in sage-grouse habitat quality following fire in Wyoming big sagebrush plant communities. Davies et al. (2009) measured a substantial exotic annual grass invasion in long-term grazing-excluded treatments in Wyoming big sagebrush plant communities postfire. However, the response of plant communities will vary significantly depending on the level of grazing and specific plant community. Historical heavy grazing had severe negative impacts on plant communities that did not evolve with high grazing pressure (Fleischner 1994; Noss 1994; Belsky and Blumenthal 1997; Jones 2000). For example, heavy grazing can promote exotic annual grass invasion by decreasing native plants (Daubenmire 1970; Mack 1981; Knapp 1996), which increases the continuity of fuels and risk of wildfire (Whisenant 1990; D'Antonio and Vitousek 1992; Davies and Svejcar 2008). Livestock grazing needs to be properly managed to promote the most benefit and reduce negative impacts. Comparing our results to evaluations of historical grazing impacts (Fleischner 1994; Noss 1994; Belsky and Blumenthal 1997; Jones 2000) supports Borman's (2005) statement that historical livestock grazing is not the same as current appropriately managed cattle grazing.

\section{MANAGEMENT IMPLICATIONS}

Moderate levels of long-term cattle grazing have significant impacts on fuel characteristics and subsequently may alter the risk, size, severity, and continuity of wildfires on sagebrush rangelands. Our results suggest that moderate livestock grazing reduces the risk of wildfires on sagebrush rangelands by decreasing the amount of fine fuel available for ignition and limiting potential fire spread by reducing fine fuel continuity, accumulation, and height. The reduction in potential spread of fire in long-term moderately grazed sagebrush plant communities can also increase the efficiency of suppression efforts. Sagebrush rangelands that are long-term moderately grazed compared to long-term not grazed would be more difficult to burn with prescribed fires, but may be more likely to produce a mosaic burn effect. The appropriateness of extrapolating the results of this study to short-term livestock grazing exclusion has not been determined and thus caution must be exercised when assuming the effects of short-term grazing exclusion. Due to altered fuel characteristics, moderate livestock grazing may elongate the length of fire return interval on native rangelands. This would be a concern in rangelands that progress from herbaceous and woody co-dominant plant communities to woody dominant plant communities without periodic fire (e.g., Archer et al. 1995). Thus, in these rangelands, active prescribed burning may also be needed to maintain desired plant communities. The potential severity of wildfires or prescribed fires is decreased because of a reduction in fuel accumulations with moderate levels of grazing and probably, more importantly, a reduction in fuel loading on perennial bunchgrass crowns. By reducing the potential severity and probability of wildfires in sagebrush rangelands, moderate grazing compared to long-term grazing exclusion may decrease the risk of exotic plant invasions. Our results suggest long-term grazing exclusion compared to moderate livestock grazing would increase the probability that sagebrush steppe plant communities would burn. Increased probability of wildfire is a concern because Beck et al. (2009) and Rhodes et al. (2010) reported that fire decreases the habitat value of less productive sagebrush plant communities to sagebrush obligate wildlife species. Thus, we 
suggest that there are some potentially negative consequences that must be fully considered before implementing long-term livestock grazing exclusion in sagebrush plant communities and probably other semi-arid and arid plant communities. The results of this study and Davies et al. (2009) suggest that fuel management research in rangelands is needed to adequately quantify the impacts of different management scenarios on fuels and subsequently fires to protect and maintain desired plant communities and the fauna indigenous to those plant communities.

\section{ACKNOWLEDGMENTS}

Assistance with data collection by Carrie Cimo, Julie Garner, Jennifer Trenary, Aleta Nafus, and Ryan Morgan was greatly appreciated. We thank Drs Dave Ganskopp and Jeremy James for reviewing earlier drafts of the manuscript. Constructive comments and thoughtful reviews by anonymous reviewers were valued.

\section{LITERATURE CITED}

Allen, C. D., M. Savage, D. A. Falk, K. F. Suckling, T. W. Swetnam, T. Schulke, P. B. Stacey, P. Morgan, M. Hoffman, and J. T. Klingel. 2002. Ecological restoration of southwestern ponderosa pine ecosystems: a broad perspective. Ecological Applications 12:1418-1433.

Archer, S., D. S. Schimel, and E. A. Holland. 1995. Mechanisms of shrubland expansion: land use, climate, or $\mathrm{CO}_{2}$ ? Climate Change 29:91-99.

Archibald, S., W. J. Bond, W. D. Stock, and D. H. K. Falrbanks. 2005. Shaping the landscape: fire-grazer interactions in an African savanna. Ecological Applications 15:96-109.

Archibald, S., D. P. Roy, B. W. Van Wilgen, and R. J. Scholes. 2009. What limits fire? An examination of drivers of burnt area in South Africa. Global Change Biology 15:613-630.

BeCK, J. L., J. W. Connelly, And K. P. Reese. 2009. Recovery of greater sage-grouse habitat features in Wyoming big sagebrush following prescribed fire. Restoration Ecology 17:393-403.

Belsky, A. J., And D. M. Blumenthal. 1997. Effects of livestock grazing on stand dynamics and soils in upland forests of the Interior West. Conservation Biology 11:315-327.

Blackmore, M., and P. M. Vitousek. 2000. Cattle grazing, forest loss, and fuel loading in a dry forest ecosystem at Pu'u Wa'aWa'a Ranch, Hawai'i. Biotropica 32:625-632.

Borman, M. M. 2005. Forest stand dynamics and livestock grazing in historical context. Conservation Biology 19:1658-1662.

Bradstock, R. A., and A. M. Gill. 1993. Fire in semi-arid, mallee shrublands: size of flames from discrete fuel arrays and their role in the spread of fire. International Journal of Wildland Fire 3:3-12.

Briggs, J. M., G. A. Hoch, AND L. C. Johnson. 2002. Assessing the rate, mechanisms, and consequences of the conversion of tallgrass prairie to Juniperus virginiana forest. Ecosystems 5:578-586.

Bunting, S. C., B. M. Kilgore, and C. L. Bushey. 1987. Guidelines for prescribed burning sagebrush-grass rangelands in the northern Great Basin. Ogden, UT, USA: USDA Forest Service, Intermountain Research Station, General Technical Report INT-231. $33 \mathrm{p}$.

Canfield, R. H. 1941. Application of the line interception methods in sampling range vegetation. Journal of Forestry 39:388-394.

Chambers, J. C., B. A. Roundy, R. R. Blank, S. Meyer, and A. Whittaker. 2007. What makes Great Basin sagebrush ecosystems invasible by Bromus tectorum? Ecological Monographs 77:117-145.

Cheney, N. P., J. S. Gould, and W. R. Catchpole. 1993. The influence of fuel, weather and fire shape variables on fire spread in grasslands. International Journal of Wildland Fire 3:31-44.
Conrad, C. E., and C. E. Poulton. 1966. Effect of a wildfire on Idaho fescue and bluebunch wheatgrass. Journal of Range Management 19:138-141.

Couteaux, M., P. Bottner, and B. Berg. 1995. Litter decomposition, climate and litter quality. Trends in Ecology \& Evolution 10:63-66.

D’Antonio, C. M., And P. M. Vitousek. 1992. Biological invasions by exotic grasses, the grass/fire cycle, and global change. Annual Reviews in Ecology and Systematics 23:63-87.

Daubenmire, R. 1970. Steppe vegetation of Washington. Pullman, WA, USA: Washington State University, Washington Agricultural Experiment Station Technical Bulletin 62. $131 \mathrm{p}$.

DAVIES, K. W. 2008. Medusahead dispersal and establishment in sagebrush steppe plant communities. Rangeland Ecology and Management 61:110-115.

Davies, K. W., AND J. D. Bates. 2010. Vegetation characteristics of mountain and Wyoming big sagebrush plant communities in the northern Great Basin. Rangeland Ecology Management 63:461-466.

Davies, K. W., J. D. Bates, and R. F. MilleR. 2006. Vegetation characteristics across part of the Wyoming big sagebrush alliance. Rangeland Ecology and Management 59:567-575.

Davies, K. W., and T. J. Svejcar. 2008. Comparison of medusahead-invaded and noninvaded Wyoming big sagebrush steppe in southeastern Oregon. Rangeland Ecology and Management 61:623-629.

Davies, K. W., T. J. SVEJCAR, AND J. D. BAtes. 2009. Interaction of historical and nonhistorical disturbances maintains native plant communities. Ecological Applications 19:1536-1545.

Derner, J. D., and A. J. Whitman. 2009. Plant interspaces resulting from contrasting grazing management in northern mixed-grass prairie: implications for ecosystem function. Rangeland Ecology and Management 62:83-88.

Dodge, M. 1972. Forest fuel accumulation: a growing problem. Science 177: 139-142.

Fleischner, T. L. 1994. Ecological costs of livestock grazing in western North America. Conservation Biology 8:629-644.

Gedalof, Z., D. L. Peterson, and N. J. Mantua. 2005. Atmospheric, climatic, and ecological controls on extreme wildfire years in the northwestern United States. Ecological Applications 15:154-174.

Holechek, J. L., R. D. Pieper, and C. H. Herbel. 1998. Range management: principles and practices. 3rd ed. Upper Saddle River, NJ, USA: Prentice-Hall, Inc. 542 p.

James, J. J., K. W. Davies, R. L. Sheley, and Z. T. Aanderud. 2008. Linking nitrogen partitioning and species abundance to invasion resistance in the Great Basin. Oecologia 156:637-648.

Jones, A. 2000. Effects of cattle grazing on North America arid ecosystems: a quantitative review. Western North America Naturalist 60:155-164.

Kerby, J. D., S. D. Fuhlendorf, And D. M. Engle. 2007. Landscape heterogeneity and fire behavior: scale-dependent feedback between fire and grazing processes. Landscape Ecology 22:507-516.

KnapP, P. A. 1996. Cheatgrass (Bromus tectorum L.) dominance in the Great Basin Desert: history, persistence, and influences to human activities. Global Environmental Change 6:37-52.

Mack, R. N. 1981. Invasion of Bromus tectorum L. into western North America: an ecological chronicle. Agro-Ecosystems 7:145-165.

Mack, R. N., And J. N. Thompson. 1982. Evolution in steppe with few large, hooved mammals. American Naturalist 119:757-773.

Mensing, S., S. Livingston, and P. Barker. 2006. Long-term fire history in Great Basin sagebrush reconstructed from macroscopic charcoal in spring sediments, Newark Valley, Nevada. Western North American Naturalist 66: 64-77.

Miller, C., and D. L. URBan. 2000. Connectivity of forest fuels and surface fire regimes. Landscape Ecology 15:145-154.

Miller, R. F., and E. K. Heyerdahl. 2008. Fine-scale variation of historical fire regimes in sagebrush-steppe and juniper woodland: an example from California, USA. International Journal of Wildland Fire 17:245-254.

MilleR, R. F., AND J. A. Rose. 1999. Fire history and western juniper encroachment in sagebrush steppe. Journal of Range Management 52:550-559.

Mitchell, S. R., M. E. Harmon, and K. E. B. O'Connell. 2009. Forest fuel reductions alters fire severity and long-term carbon storage in three Pacific Northwest ecosystems. Ecological Applications 19:643-655. 
Moghaddas, J. J., and L. Craggs. 2007. A fuel treatment reduces fire severity and increases suppression efficiency in a mixed conifer forest. International Journal of Wildland Fire 16:673-678.

Noss, R. F. 1994. Cows and conservation biology. Conservation Biology 8:613-616.

OdION, D. C., AND F. W. Davis. 2000. Fire, soil heating, and the formation of vegetation patterns in chaparral. Ecological Monographs 70:149-169.

Rhodes, E. C., J. D. Bates, R. N. Sharp, and K. W. Davies. 2010. Fire effects on cover and dietary resources of sage-grouse habitat. Journal of Wildlife Management 74:755-764.

Ritchie, M. W., C. N. Skinner, and T. A. Hamilton. 2007. Probability of tree survival after wildfire in interior pine forests of northern California: effects of thinning and prescribed fire. Forest Ecology and Management 247:200-208.

Schoennagel, T., T. T. Veblen, and W. H. Romme. 2004. The interaction between fire, fuels, and climate across Rocky Mountain forests. BioScience 54:661-676.

Schwilk, D. W., J. E. Keeley, E. E. Knapp, J. Mclver, J. D. Bailey, C. J. Fettig, C. E. Fiedler, R. J. Harrod, J. J. Moghaddas, K. W. Outcalt, C. N. Skinner, S. L. Stephens, T. A. Waldrop, D. A. Yaussy, and A. Youngblood. 2009. The national fire and fire surrogate study: effects of fuel reduction methods on forest vegetation structure and fuels. Ecological Applications 19:285-304.
Stohlgren, T. J., D. Binkley, G. W. Chong, M. A. Kalkhan, L. D. Schell, K. A. Bull, U. Otsuki, G. Newman, M. Bashkin, and Y. Son. 1999. Exotic plant species invade hot spots of native plant diversity. Ecological Monographs 69:25-46.

Waldram, M. S., W. J. Bond, and W. D. Stock. 2008. Ecological engineering by a mega-grazer: white rhino impacts on a South African savanna. Ecosystems 11:101-112.

Whisenant, S. G.. 1990. Changing fire frequencies on Idaho's Snake River Plains: ecological and management implications. In: E. D. McArthur, E. M. Romney, S. D. Smith, and P. T. Tueller [comps.]. Cheatgrass invasion, shrub die-off, and other aspects of shrub biology and management. Las Vegas, NV, USA: USDA Forest Service, Intermountain Research Station. p. 4-10.

Wimberly, M. C., M. A. Cochrane, A. D. Baer, and K. Pabst. 2009. Assessing fuel treatment effectiveness using satellite imagery and spatial statistics. Ecological Applications 19:1377-1384.

Wright, H. A., and A. W. Balley. 1982. Fire ecology: United States and Southern Canada. New York, NY, USA: John Wiley and Sons. 528 p.

Zimmerman, G. T., and L. F. Neuenschwander. 1984. Livestock grazing influences on community structure, fire intensity, and fire frequency within the Douglas-fire and ninebark habitat type. Journal of Range Management 37:104-110. 